\title{
The Quaternary palaeobotany of Madeira and Azores volcanic archipelagos (Portugal): insights into the past diversity, ecology, biogeography and evolution
}

\author{
Carlos A. Góis-Marques ${ }^{1,2,3}$ \\ ${ }^{1}$ Departamento de Geologia, Faculdade de Ciências da Universidade de Lisboa, Campo Grande, 1749-016, Lisbon, Portugal \\ ${ }^{2}$ Instituto Dom Luiz (IDL), Laboratório Associado, Universidade de Lisboa, Campo Grande, 1749-016, Lisbon, Portugal \\ ${ }^{3}$ Madeira Botanical Group (GBM), Faculdade de Ciências da Vida, Universidade da Madeira, Campus da Penteada, \\ 9000-390, Funchal, Portugal
}

Correspondence: Carlos A. Góis-Marques (c.goismarques@gmail.com)

Relevant dates: $\quad$ Received: 14 May 2021 - Accepted: 9 August 2021 - Published: 6 September 2021

How to cite: $\quad$ Góis-Marques, C. A.: The Quaternary palaeobotany of Madeira and Azores volcanic archipelagos (Portugal): insights into the past diversity, ecology, biogeography and evolution, E\&G Quaternary Sci. J., 70, 197-199, https://doi.org/10.5194/egqsj-70-197-2021, 2021.

Supervisor: José Madeira (University of Lisbon)

Co-supervisors: José María Fernández-Palacios (University of La Laguna), Miguel Menezes de Sequeira (University of Madeira)

Dissertation online: https://doi.org/10.13140/RG.2.2.25325. 10729

Palaeobotanical research on oceanic islands has been largely ignored despite its importance for providing empirical proof to disentangle insular plant diversity, evolution, ecology and biogeography. Here we use the oceanic archipelagos of Madeira and the Azores as a "testing ground" (Fig. 1a), via fieldwork and laboratorial and collection-based research, to demonstrate the existence of well-preserved and palaeobiologically informative plant fossils (Góis-Marques, 2020). In Madeira, mid-19th century collections from the São Jorge leaf bed (Fig. 2b) were stratigraphically and taxonomically reappraised, revealing the presence of the stink-laurel forest at 7-1.8 Ma, similar to the extant community (GóisMarques et al., 2018). Porto da Cruz sediment exploration and new ${ }^{40} \mathrm{Ar}-{ }^{39} \mathrm{Ar}$ dating revealed the existence at $1.3 \mathrm{Ma}$ of the extinct Eurya stigmosa (Theaceae) (Fig. 1d; GóisMarques et al., 2019d), the neoendemic Melanoselinum de- cipiens (Apiaceae) (Fig. 1c; Góis-Marques et al., 2019a) and the probable ancestor of the Madeiran besom heath, Erica sect. Chlorocodon (Ericaceae). Preliminary prospection and dating of limnic sediments revealed the presence of suitable Pleisto-Holocene palynological content for palaeoecological reconstruction. In the Azores archipelago, the historical fossil collection (Góis-Marques and Menezes de Sequeira, 2015) and palaeobotanical review revealed the existence of plant fossils on all the islands (Fig. 1g; Góis-Marques et al., 2019b). On Faial, charcoalified wood found within the 1200-year BP ignimbrite (Fig. 1e) revealed the presence of abundant Prunus lusitanica subsp. azorica (Fig. 1f), today a rare endemic tree due to anthropic impacts (Góis-Marques et al., 2020). Fanal Bay leaf beds (Terceira) were prospected during 2016, revealing an in situ leaf litter forest, but these were destroyed in 2018 despite being within the Azores UNESCO global Geopark (Góis-Marques et al., 2019c). Here we demonstrate, for both archipelagos, the presence of an abundant and well-preserved plant fossil record, ranging probably from the Miocene but mostly Pleistocene to Holocene (Fig. 1g). These plant fossils are valuable, as they provide minimum ages for future phylogeny calibration and clues on the evolution of insular syndromes and allow the inference of 

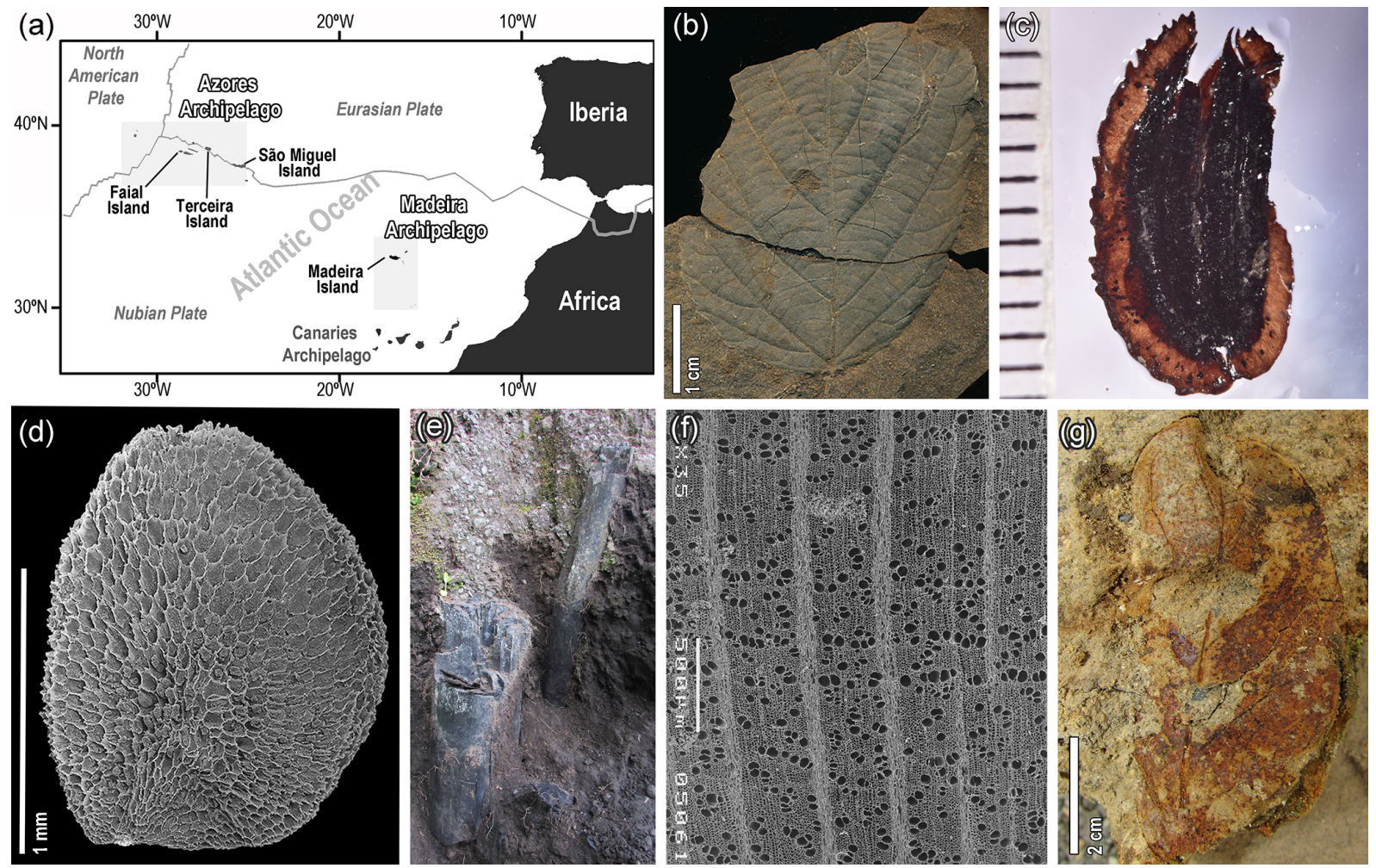

Figure 1. (a) Geographical locations and tectonic settings of the Madeira and Azores archipelagos and the respective islands studied in this thesis; (b) specimen ETH-Z-ERDW 5739 currently deposited at the Departement Erdwissenschaften-Eidgenössische Technische Hochschule (Zurich, Switzerland), collected in the mid-19th century in São Jorge, Madeira. This specimen was identified as Corylus australis, an extinct taxon described in Heer (1857) but revised in Góis-Marques et al. (2018) as a Rubus sp. leaflet, a native genus in Madeira; (c, d) fruit and seed fossils from the 1.3 Ma Porto da Cruz sediments, Madeira: (c) Melanoselinum (三Daucus) decipiens (Apiaceae) fossilized mericarps, representing the oldest fossil of a carrot and the first fossil evidence of insular woodiness (Góis-Marques et al., 2019a; scale bar in millimetres); (d) scanning electronic microscopy (SEM) image of a seed fossil of Eurya stigmosa (Theaceae), a new and extinct plant for Madeira. Reprinted from Góis-Marques et al. (2019d), (C) 2021 with permission from Elsevier; (e) charcoalified trunks buried in situ within a 1200-year BP ignimbrite on Faial, Azores; (f) SEM image of a transverse section of a charcoalified trunk of Prunus lusitanica subsp. azorica (found in the same locality shown in panel e); (g) example of an unidentified lauroid leaf fossil found in ash tuff 1200 years BP on Faial.

the anthropic impact on pristine insular vegetation. However, this information can only be retrieved if the palaeobotanical geoheritage in these archipelagos is protected and properly studied.

Data availability. The papers that constitute this thesis are published or submitted (see reference list).

Competing interests. The contact author has declared that there are no competing interests.

Disclaimer. Publisher's note: Copernicus Publications remains neutral with regard to jurisdictional claims in published maps and institutional affiliations.
Acknowledgements. This thesis was supported by the SYNTHESYS project (GB-TAF-3203; http://www.synthesys.info/, last acess: 10 May 2021), which is financed by the European Community Research Infrastructure Action under the FP7 Integrating Activities Programme.

Financial support. This research has been supported by the ARDITI - Regional Agency for the Development of Research, Technology and Innovation project (PhD grant: M1420-09-5369FSE-000001).

The article processing charge was funded by the Quaternary scientific community, as represented by the host institution of $E G Q S J$, the German Quaternary Association (DEUQUA).

Review statement. This paper was edited by Daniela Sauer and reviewed by one anonymous referee. 


\section{References}

Góis-Marques, C. A.: The Quaternary palaeobotany of Madeira and Azores volcanic archipelagos (Portugal): insights into the past diversity, ecology, biogeography and evolution, unpublished $\mathrm{PhD}$ thesis, Departamento de Geologia, Faculdade de Ciências da Universidade de Lisboa, Portugal, XLVIII+426 pp., 2020.

Góis-Marques, C. A. and Menezes de Sequeira, M.: Darwin, Hooker and Arruda Furtado and the palaeobotany of Azores: Rediscovering the first collections, Rev. Palaeobot. Palynol., 221, 47-51, https://doi.org/10.1016/j.revpalbo.2015.05.010, 2015.

Góis-Marques, C. A., Madeira, J., and Menezes de Sequeira, M.: Inventory and review of the Mio-Pleistocene São Jorge flora (Madeira Island, Portugal): palaeoecological and biogeographical implications, J. Syst. Palaeontol., 16, 159-177, https://doi.org/10.1080/14772019.2017.1282991, 2018.

Góis-Marques, C. A., de Nascimento, L., Fernández-Palacios, J. M., Madeira, J., and Menezes de Sequeira, M.: Tracing insular woodiness in giant Daucus (s.1.) fruit fossils from the Early Pleistocene of Madeira Island (Portugal), Taxon, 68, 1314-1320, https://doi.org/10.1002/tax.12175, 2019a.

Góis-Marques, C. A., de Nascimento, L., Menezes de Sequeira, M., Fernández-Palacios, J. M., and Madeira, J.: The Quaternary plant fossil record from the volcanic Azores Archipelago (Portugal, North Atlantic Ocean): a review, Hist. Biol., 31, 1267-1283, https://doi.org/10.1080/08912963.2018.1444761, 2019b.
Góis-Marques, C. A., Elias, R. B., Steinbauer, M. J., de Nascimento, L., Fernández-Palacios, J. M., Menezes de Sequeira, M., and Madeira, J.: The loss of a unique palaeobotanical site in Terceira Island within the Azores UNESCO global geopark (Portugal), Geoheritage, 11, 1817-1825, https://doi.org/10.1007/s12371019-00401-1, 2019c.

Góis-Marques, C. A., Mitchell, R. L., de Nascimento, L., Fernández-Palacios, J. M., Madeira, J., and Menezes de Sequeira, M.: Eurya stigmosa (Theaceae), a new and extinct record for the Calabrian stage of Madeira Island (Portugal): ${ }^{40} \mathrm{Ar} /{ }^{39} \mathrm{Ar}$ dating, palaeoecological and oceanic island palaeobiogeographical implications, Quat. Sci. Rev., 206, 129-140, https://doi.org/10.1016/j.quascirev.2019.01.008, 2019d.

Góis-Marques, C. A., Rubiales, J., de Nascimento, L., Menezes de Sequeira, M., Fernández-Palacios, J. M., and Madeira, J.: Oceanic Island forests buried by Holocene (Meghalayan) explosive eruptions: palaeobiodiversity in pre-anthropic volcanic charcoal from Faial Island (Azores, Portugal) and its palaeoecological implications, Rev. Palaeobot. Palynol., 273, 104116, https://doi.org/10.1016/j.revpalbo.2019.104116, 2020.

Heer, O.: Ueber die fossilen Pflanzen von St. Jorge in Madeira, Neue Denkschr. Allg. schweiz. Ges. ges. Naturw., Band XV, 1$40,1857$. 